\title{
THE CORRELATION BETWEEN THE OPERATING CONDITIONS OF AN OIL TANKER AND FUEL CONSUMPTION
}

\author{
Mariana LUPCHIAN \\ "Dunarea de Jos" University of Galati, Romania \\ e-mail: mariana.lupchian@ugal.ro
}

\begin{abstract}
This paper presents a calculation method to determine optimum operating conditions of power plants installations with internal combustion engines used on ships. The scope of this document is to make a minimum fuel consumption calculation using software Engineering Equation Solver. Analysing several operating regimes, the specific consumption of heavy fuel used on the main engine of the oil tanker is calculated. Vessel must operate at the parameters for which it was designed and built, thus satisfying all technical and economic aspects.
\end{abstract}

KEYWORDS: fuel consumption, oil tanker, propeller, operating regimes, internal combustion engines

\section{Introduction}

The propulsion engines operating in different exploitation conditions was determined by the technical condition of the ship and the propulsion plant and external factors that have an influence on the operation $[1,5]$.

A power plant with internal combustion engine is a heat power plant mainly processing the chemical energy of the fuel used, and transformed into heat energy from combustion processes and mechanical work necessary for its consumers [2].

The main engine of a ship is the main fuel consumer and major energy manufacturer on board.

By introducing the technical state, as an independent variable, there must be taken into consideration the periods of time in which the fixing of the capital naval propulsion plant must be done, as well as the ship docking, in order to clean the careen etc., so the exploitation costs be minimum [3].

The fundamental purpose of the activities performed during the operation, maintenance of the propulsion installation and of the hull of the ship is the maintenance of the marching qualities during its entire service life.

When carrying out the propulsion of ships, in principle, two basic requirements are imposed: ensuring the prescribed speed of the ship and minimizing fuel consumption.

When choosing the number of engines and shaft line elements, the full load draft and the ballast ship draft are taken into account, determining the diameter, optimum speed, propeller efficiency and total engine power necessary to achieve the speed required by the design theme $[1,9]$.

\section{Study on fuel consumption for several operating regimes}

The paper is a continuation of a study on a 37000 tdw oil tanker. The studied oil tanker is equipped with a diesel engine MAN B \& W \& 6cylinder, engine power: 9480 [KW], 127 [rpm].

The main mechanical characteristics of compression ignition engines at optimum thermal regimes are given by the following dependencies:

- Pe $[\mathrm{kW}]$ - effective engine power;

- $\mathrm{n}$ [rpm] - engine speed;

- $\mathrm{h}$ - position of the control system of the injection system [5].

The vessel must operate at the parameters for which it was designed and built, thus satisfying all technical and economic aspects [5, 7].

Fuel efficiency is reliant on several parameters of a vehicle, including engine parameters, aerodynamic, weight and rolling resistance.

In order to improve ship propulsion an installation is used for main marine diesel fuel with sulphur heavy fuel oil, that is especially hard to slow diesel engines and diesel engines semirapid ones [5, $6]$.

The selection of the type of propulsion system must be the result of a technical-economic analysis, which takes into account all the factors on which the 
safety and economy ship is used. The vessel must operate at the parameters for which it was designed and built, satisfying all the competitiveness aspects, both technically and economically [4].

The resistance to progress is one of the most important qualities for navigation, which depends on the power of the propulsion system $[3,5,8]$.
The J. Holtrop and G. G. J. Mennen methods have been used to determine the ship's forward resistance [10].

The advantage of this method is that it can be easily programmed in order to achieve an optimization program. by:

Ship resistance in advancement $\mathrm{R}(\mathrm{kN})$ is given

$$
R=R_{F}\left(1+k_{1}\right)+R_{A P}+R_{W}+R_{B}+R_{T R}+R_{A}
$$

where:

$1+k_{1}$ - form factor linking the viscosity resistance of the body in conjunction with abrasion resistance $R_{F}[5,9,10]$

$$
\begin{aligned}
& R_{A P} \text { - resistance apendincs; } \\
& R_{W} \text { - wave resistance; } \\
& R_{B} \text { - additional pressure density of the bulb }
\end{aligned}
$$
near the water surface;

$R_{T R}$ - density of the additional pressure of
$R_{A}$-strength of the correlation model ship (correction of roughness).

The propulsion factors are calculated at several operating regimes, considering the ship loaded and ballasted.

Figure 1 shows Rt [kW] depending on the speed of the ship [Nd] (for the loaded and ballasted ship).

For several operating modes, it is calculated the power of the propulsion engine, the towing power, the power available at the propeller $\left(\mathrm{P}_{\mathrm{rem}}, \mathrm{P}_{\mathrm{el}}, \mathrm{P}_{\mathrm{MP}, \mathrm{m}}\right)$ [5]. stern cut;

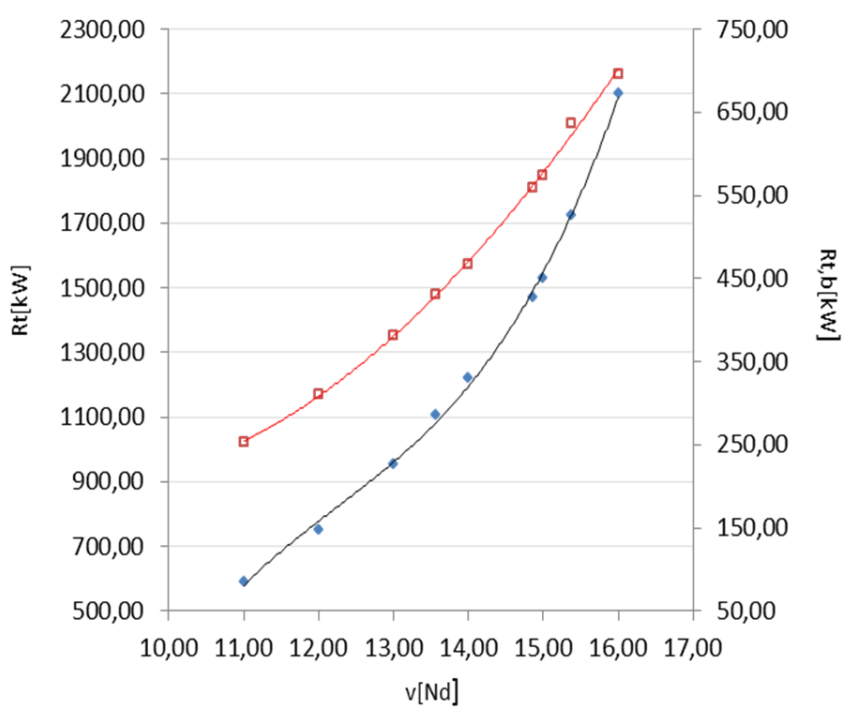

Fig. 1. Resistance to the advancement of the ship

Figure 2 shows $\mathrm{R}_{\mathrm{t}}, \mathrm{P}_{\mathrm{rem}}, \mathrm{P}_{\mathrm{el}}, \mathrm{P}_{\mathrm{MP}}$ depending on the speed $[\mathrm{Nd}]$ for different operating modes.

The dependence of power of towing of the ship, the power required to drive the propeller, relies on the engine power propulsion and the resistance to progress of the ship (full load).

The actual specific fuel consumption was calculated according to the propeller characteristic (full load) for some of the analyzed operating modes.

The forward resistance of the ship $R=f(T j)$, the loaded ship has the draft $\mathrm{Tj}=10.5 \mathrm{~m}$.
The specific fuel consumption is determined according to the hourly fuel consumption and the effective power of the main engine.

Considering the ship defined as a subsystem of the operating system, through the main characteristics (capacity, speed, autonomy, etc.), there is the problem of establishing the form, energy and functional parameters that determine the optimal operating conditions for the given ship.

$c_{\mathrm{s} 1}$ - the actual effective fuel consumption for the loaded ship; 


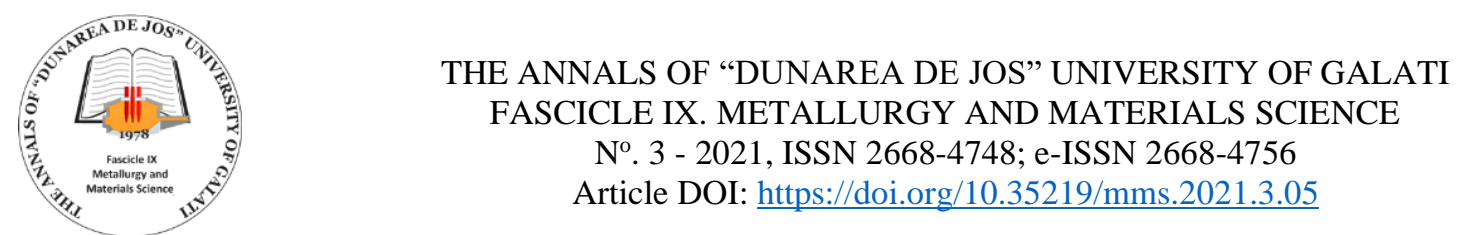

$\mathrm{c}_{\mathrm{s} 2}$ - the actual effective fuel consumption for the ballast ship;

Figure 3 shows the specific consumption of heavy fuel $\mathrm{c}_{\mathrm{s} 1}, \mathrm{c}_{\mathrm{s} 2}$ for the analyzed operating regimes.

The main factor for the specific cost is the fuel

consumption of the energetic plant with internal combustion engines, for which the optimum control proportions, which assure the optimal functioning regimes, must be found. [4] consumption- which actually means the minim fuel

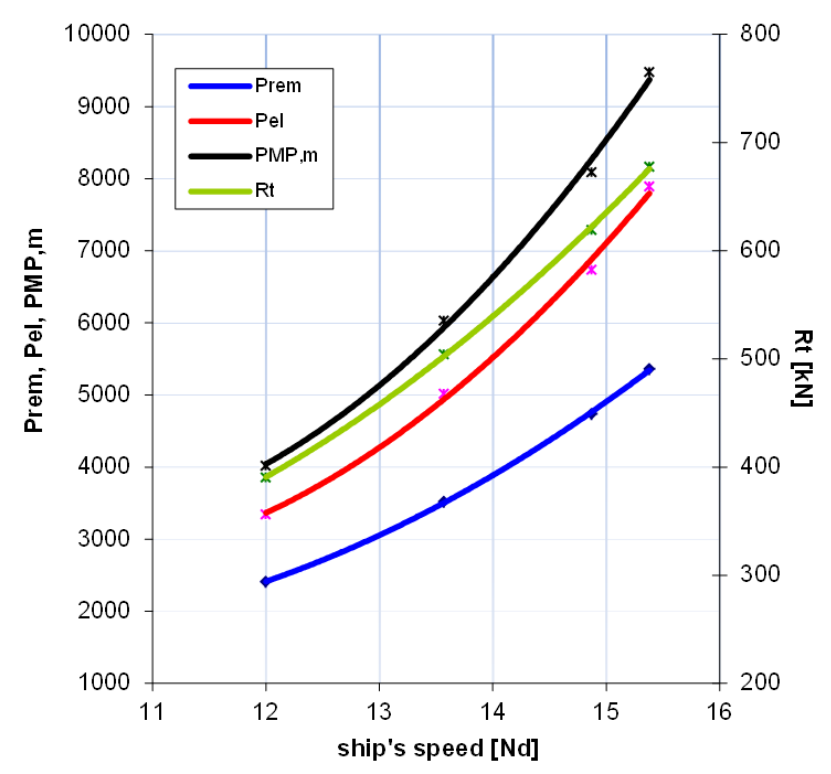

Fig. 2. $R_{t}, P_{\text {rem }}, P_{e l,} P_{M P}$ - depending on the speed of the ship

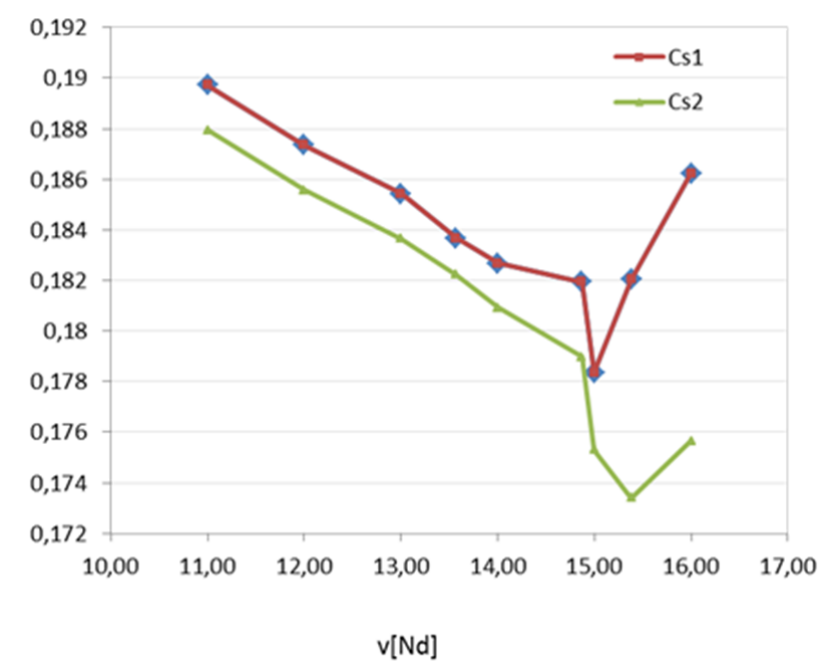

Fig. 3. The specific effective consumption of fuel (loaded ship and ballasted)

\section{Obtained results}

The energetic and functional parameters result from the analysis of the navigation regimes considered representative for the operation of the ship in the conditions imposed by the considered transport system.

Fuel consumption is the main factor that determines the specific cost, which is actually a minimum specific fuel consumption for minimum naval propulsion plant.

Fuel efficiency is reliant on several parameters of a vehicle, including engine parameters, aerodynamic, weight and rolling resistance.

In order to improve ship propulsion an installation is used for main marine diesel fuel with sulphur heavy fuel oil that is especially hard to slow diesel engines and diesel engines semirapid. 


\section{THE ANNALS OF “DUNAREA DE JOS” UNIVERSITY OF GALATI \\ FASCICLE IX. METALLURGY AND MATERIALS SCIENCE \\ $\mathrm{N}^{\circ} .3$ - 2021, ISSN 2668-4748; e-ISSN 2668-4756 \\ Article DOI: https://doi.org/10.35219/mms.2021.3.05}

The actual specific fuel consumption of the propulsion engine was determined by the propeller characteristic, for several operating and running modes; resulted in an optimum speed of $15 \mathrm{Nd}$ for the loaded ship with a minimum specific consumption of $0.17835 \mathrm{~kg} / \mathrm{kWh}$ and an optimal speed of $15.38 \mathrm{Nd}$ for the ballasted ship with a minimum specific consumption of $0.1734 \mathrm{~kg} / \mathrm{kWh}$.

Figure 4 and 5 show the specific effective consumption of heavy fuel used by the propulsion engine of the oil tanker.

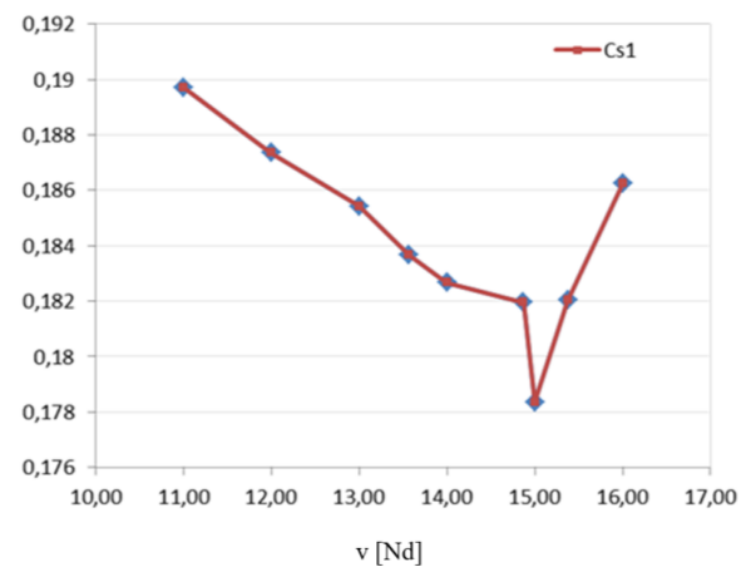

Fig. 4. The specific effective consumption of fuel depending on ship speed [Nd] (loaded ship)

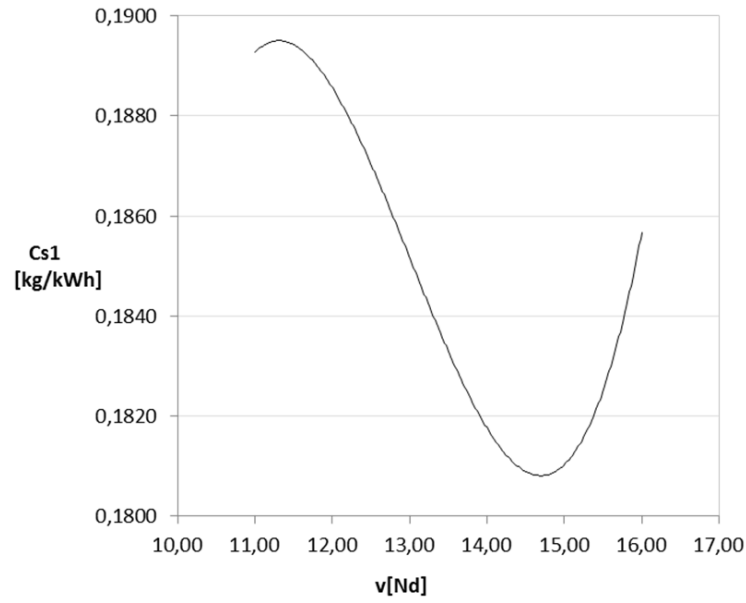

Fig. 5. Minimum fuel consumption

\section{References}

[1]. Simionov Mihai, Instalații de maşsini, Galati University Press, Editura Universității "Dunărea de Jos" din Galați, 2018.

[2]. Lupchian Mariana, The influence of propulsion factors on the functioning regimes of a naval power plant, Constanta Maritime University Annals, vol. 21, Publisher: Constanta Maritime University, ISSN: 1582-3601, 2014.

[3]. Lupchian Mariana, Analysis of the operating regimes of power plants for different situations naval navigation, SECTION I - Navigation and Maritime Transport, Constanţa Maritime University Annals, vol. 19, p 51, Editura Nautica, 2013.

[4]. Lupchian Mariana, Determination of optimum operating regime for a naval power plant based on minimum fuel consumption, ModTech International Conference - New face of
TMCR, Modern Technologies, Quality and Innovation, New face of TMCR, 24-26 May, Sinaia, Romania, 2012.

[5]. Lupchian Mariana (Caraghiulea Mariana), Contribuţii la optimizarea regimurilor de funcţionare ale instalaţiilor energetice cu motoare cu ardere internă, PhD thesis, Galati, 2012.

[6]. Simionov Mihai, Instalaţii de propulsie navale. Linii de arbori navale, Editura Evrika, Brăila, 2001.

[7]. ***, The Motor Ship, Waste management is a grey area for owners, 2001.

[8]. Simionov Mihai, Instalaţii de propulsie navală, Galati University Press, 2009.

[9]. Ceangă V., Mocanu C. I., Teodorescu C., Dinamica sistemelor de propulsie, Editura Didactică şi Pedagogică, Bucuresti, 2003.

[10]. Bidoaie I., Sarbu N., Chirica I., Ionaş O., Indrumar de proiectare pentru teoria navei, p. 169-178, Universitatea Dunarea de Jos, Galati, 1986. 